\title{
Nieuświadomione dziedzictwo? Ukryte analogie w twórczości Milana Kundery i Karla Čapka
}

\author{
AGNIESZKA JANIEC-NYITRAI \\ ELTE BTK Szláv és Balti Filológiai Intézet, H-1088 Budapest, Múzeum krt. 4/D. \\ E-mail: janiec.nyitrai@gmail.com
}

(Received: 12 July 2016; accepted: 27 September 2016)

\begin{abstract}
This article is devoted to certain themes, problems, and motifs known as key questions in the literary heritage of the interwar period Czech writer Karel Čapek, which can be seen in Milan Kundera's prose as well. The author depicts and briefly characterizes the most important points of contact in the works of these two prominent writers, focusing on narrative similarities and examining analogies which appear at the semantic level: a search for identity, a fascination with diversity and difference, or the concept of "unrealized lives", to name only a few. Another important aspect of the study is the question of searching for the truth and its ambiguity, which is the key problem in Čapek's works, and it also plays a very important role in Kundera's prose. Finally, the theme of ambiguous and unstable identity is also explored, the identity that constantly changes under the influence of the "watchful gaze of others".
\end{abstract}

Keywords: Karel Čapek, Milan Kundera, Czech literature, literary heritage, analogies

Wydawać by się mogło, że twórczość Milana Kundery i Karla Čapka dzieli nieprzekraczalny, uniemożliwiający porównanie czasowy dystans, jednak jeśli spojrzymy na daty urodzin obu autorów, zauważymy, że różni je jedynie 40 lat. Oczywiście trzeba wziąć pod uwagę traumatyczne, zmieniające paradygmat kultury doświadczenia II wojny światowej, a także w przypadku Kundery dodatkowe doświadczenie komunizmu, niewątpliwie wpływające na jego sposób postrzegania świata. Wojna i komunizm wyraźnie zintensyfikowały szybkość zmian społecznych i politycznych, przerwały naturalny bieg rozwoju kultury oraz wpłynęły na to, iż twórczość obu pisarzy dzieli wiele. Wydawać się może, że w dorobku pisarskim Milana Kundery trudno doszukiwać się podobieństw z twórczością Čapka czy też jakichkolwiek inspiracji dziełem międzywojennego pisarza. Niemiej jednak owe poszukiwania zdają się być według mnie uzasadnione, co postaram się pokazać w tym artykule, a istnienie ukrytych analogii zasygnalizowali już zresztą uznani czescy bohemiści (na przykład, KuBíčEK 2007: 131-132, KosKOvÁ 1996: 96).

W swoim artykule podążę śladem zainicjowanych przez nich badań, dodając jednocześnie kilka nowych spostrzeżeń. Skoncentruję się na istnieniu podobieństw w budowie narracyjnej utworów, chciałabym także przybliżyć nieprzypadkowe moim zdaniem analogie pojawiające się $\mathrm{w}$ warstwie semantycznej: kwestie poszukiwania tożsamości, fascynację różnorodnością i różnica, koncepcję „niezrealizowanych żywotów", występującą u Čapka, a przez Kunderę twórczo rozwiniętą. Tym samym postaram się rozpoznać moim zdaniem najistotniejsze paralele w twórczości obu pisarzy. 
Interesujący wydaje się fakt, iż Kundera w rozważaniach poświęconych swojej twórczości często powołuje się na duchowe pokrewieństwo z Witoldem Gombrowiczem, pisarzami francuskimi, wspomina także o środkowoeuropejskich prozaikach - Franzu Kafce czy Robercie Musilu, odnotowując ich konkretne wpływy intelektualne, lecz nie wspomina nigdy w takim kontekście Karla Čapka. Kundera odnosi się natomiast do niego bezpośrednio, podkreślając swoją niechęć do tworzenia poezji. Wówczas to wspomina słowa autora R.U.R., który na pytanie, dlaczego nie pisze wierszy odpowiedział: „Protože nerád mluvím o sobě” (KunDERA 2014: 33-34). Kwestie te są na tyle zastanawiające, że wspominam o nich, choć nie jest moim celem odpowiedź na pytanie, dlaczego Kundera pomija Čapka w swoich rozważaniach o inspiracjach literackich i intelektualnych. Będę natomiast starała się pokazać owe podobieństwa.

\section{Podwójna polifonia}

W przypadku twórczości Milana Kundery polifonia w warstwie narracyjnej realizuje się, według Tomaša Kubíčka, jako wielogłos narracyjny, ale także jako pewien synkretyzm gatunków i rodzajów literackich (KuBíčEK 2012: 66). Pozostaje to $\mathrm{w}$ zgodzie z zaproponowanym przez polskich badaczy wyodrębnieniem ,,polifonii semantycznej” (wieloznaczeniowości) i ,polifonii stylistycznej” (wielostylowości) (KuIŚ 2011: 25). Rozszczepienie perspektywy narracyjnej i polifonię narracji można zaliczyć do kluczowych i najważniejszych metod, które wykorzystuje w swojej twórczości Čapek. W ten sposób zbudowana jest tzw. trylogia noetyczna Hordubal (1933), Povetroň (1934), Obyčejný život (1934), w której poszczególne postaci, wydarzenia, czyny, pokazane są z różnych perspektyw, a pisarz naświetla je z bliska, z daleka, w różnych konfiguracjach, sam utożsamiając się z niektórymi postaciami, a potem nagle ową bliskość naruszając (JANIEC-NYITRAI 2016b: 137). Podobną technikę zastosował Čapek także w ostatniej niedokończonej powieści Život a dilo skladatele Foltýna (1939). Tytułowego bohatera poznajemy poprzez relacje osób, które weszły z nim w bliższe i dalsze relacje, a tym, kto posiada o Foltýnie najwięcej informacji, staje się sam czytelnik, bowiem przed poszczególnymi postaciami pozostają ukryte interpretacje innych osób.

W twórczości Kundery polifoniczną narracją odznacza się przede wszystkim debiutancka powieść Žert (1965), składająca się z siedmiu rozdziałów nazwanych imionami poszczególnych bohaterów: Ludvíka, Kostka, Jaroslava i Heleny. Kundera sam precyzyjnie odsłania konstrukcję swojej powieści: „Monolog Ludwika zajmuje 2/3 książki, monologi pozostałych zajmują w sumie 1/3 (Jarosława 1/6, Kostki 1/9, Heleny 1/18). Ta matematyczna struktura określa to, co nazwałbym oświetleniem postaci. Ludwik występuje w pełnym świetle, jest oświetlony od wewnątrz (przez własny monolog) i z zewnątrz (jego portret kreślą monologi innych). Jarosław zajmuje swoim monologiem jedną szóstą książki, a jego autoportret jest skorygowany z zewnątrz przez monolog Ludwika. I tak dalej" (KunDERA 1998: 80). 
Na analogię w kompozycji powieści z metodą stosowaną przez Čapka zwróciła uwagę Helena Kosková: „Román je komponován jako vyprávění čtyř postav, kteří připomínají jakési čapkovské vidění jednoho př́iběhu z mnoha stran: jenže tady nemá každý svou pravdu, ale svůj omyl” (KosKová 1996: 96). Kosková podkreśla podobieństwo formy, ale ogólne treściowe przesłania obu tekstów według niej rozmijają się. Jednk wydaje mi się, że i w przypadku Čapka nie zawsze chodzi o własną prawdę, własną rację bohaterów, często, jak na przykład w powieści Hordubal, zobrazowana jest iluzja prawdy. Kundera w Sztuce powieści tak charakteryzuje prawo do głosu, prawo do prawdy i prawo do błędu każdej ze stron konfliktu: „Powieść jest wyobraźniowym rajem indywidualności... przestrzenią, w której nikt, ani Anna, ani Karenin, nie jest panem prawdy, lecz wszyscy, tak Anna, jak i Karenin, maja prawo do zrozumienia" (KUNDERA 1998: 139).

I u Kundery, i u Čapka opowieść odsłania się właśnie w narracjach poszczególnych postaci, tworząc mozaikę. Czytelnik poznając „,wersje” prezentowane przez poszczególnych bohaterów, zyskuje możliwość poznania pełnej historii. Poszczególnym zdarzeniom oświetlonym różnym światłem zostaje porządkowana nowa wartość, nowe znaczenie. Przestają być płaskie, jednoznaczne. Konkretne postaci w odmienny sposób interpretują poszczególne zdarzenia, oceniają je z innej perspektywy. Rzeczywistość zostaje przedstawiona jako niejednoznaczna, niedokończona, także przeszłość staje się otwarta, zależna od różnych interpretacji, opinii, punktów widzenia. Każdy element rzeczywistości otwarty jest zatem na reinterpretacje. Dochodzi do konfrontacji poszczególnych ocen konkretnych zdarzeń, rzeczywistość rozwarstwia się.

Pozostaje to w zgodzie z zaproponowanym przez Michaiła Bachtina pojęciem powieści polifonicznej, które Beata Kliś definiuje następująco: „W powieści polifonicznej występuje bowiem równocześnie kilka głosów, przy czym żaden z nich nie jest dominujący, żaden nie może także oceniać pozostałych. Oznacza to, że głos postaci literackiej nie zostaje opatrzony komentarzem narratorskim. Narrator ogranicza się do zestawienia i konfrontacji różnych punktów widzenia, różnych stanowisk" (KLIŚ 2011:29).

To samo widać wyraźnie w powieści Žert, gdzie Kundera zastosował identyczną technikę jak Čapek w swojej ostatniej, niedokończonej powieści. Prawda, która wydawała się być monolityczna, nagle traci swoją jednoznaczność: „Projevy vypravěčủ Žertu jsou stylizovány tak, aby se alespoň občas objevila znamení vybízející všimnout si, že je nějaký nesoulad mezi viditelnými slovy, gesty a jednáním a mezí tím, co je schováno, neviditelné, skutečné” (PoHORSKÝ 1990: 272). W gładkiej i na pierwszy rzut oka jednolitej rzeczywistości otwiera się nagle przepaść, pojawiają się w niej pęknięcia, ukryte skazy. Dochodzi do odkrycia skomplikowanej natury świata, do uświadomienia sobie pogmatwanych motywacji, pokazania wzajemnie się wykluczających prawd, wzajemnie ze sobą powiązanych iluzji, podobnie jak u Čapka zdemaskowana jest głęboka niekoherencja rzeczywistości, jej polisemia. Kundera w Sztuce powieści podkreśla, że „rzeczy są bardziej złożone niż myślisz", a powieść nie pozwala zadowalać się prostą redukcją do łatwej odpowiedzi (KUNDERA 2005: 25). 
Kundera zmienia perspektywy także w innych powieściach, nazywając każdą nową perspektywę ,wieżą obserwacyjną” (,rozhledna”). Swoją metodę prowadzenia narracji przybliża na początku szóstego rozdziału powieści Život je jinde, w którym rozważa potrzebę zmiany perspektywy (KunDERA 1979: 307-309). Według Květoslava Chvatíka Kundera pragnie w ten sposób zobiektywizować narrację, pragnie pokazać inny punkt widzenia, wyeksponować nowe sposoby rozumienia tekstu (ChVATíK 1994: 60).

W kolejnej powieści Kniha smíchu a zapomnění (1979) pisarz idzie o krok dalej w swoim eksperymentowaniu ze zmianami perspektywy. Występują tam wariacje poszczególnych motywów, ich wzajemne przenikanie się, czemu towarzyszy rezygnacja z klasycznej narracji (KuBíčEK 2012: 67). W powieści tej pojawiają się eseistyczne dygresje, które staną się znakiem rozpoznawczym prozy Milana Kundery, co bezpośrednio związane jest z drugim typem polifonii, o której wspominał Kubíček - mieszaniem się gatunków i rodzajów literackich.

U Karla Čapka synkretyzm gatunkowy jest szczególnie widoczny w powieści Válka s mloky, gdzie czeski pisarz „bawi się”, stwarzając tekst - kolaż, będący kompilacją różnych, diametralnie niekiedy różniących się od siebie gatunków literackich (powieść przygodowa, science fiction, fragmenty tekstów naukowych, urywki z encyklopedii, artykuły prasowe itd.), ale także wykorzystując różne style językowe. Powieść ta jest jednym z najlepszych przykładów polifonii językowej, o której Jan Grzenia pisze: „Wielojęzykowość, czyli polifonia językowa polega na utkaniu materii językowej utworu literackiego z elementów niejednorodnych pod względem społecznym i funkcjonalnym, tzn. $z$ jednostek dowolnego poziomu językowego, które mogą zostać zidentyfikowane jako należące do różnych odmian języka (i co za tym idzie - odmian mowy/pisma, gatunków mowy/pisma, stylów indywidualnych i ponadindywidualnych)" (GRZENIA 1999: 43).

Niejednorodna gatunkowo, ale także językowo, jest też pierwsza część trylogii noetycznej Hordubal, która jest jednocześnie balladą, kryminałem i powieścią filozoficzną, co było Čapkowi zarzucane. Miesza się w niej gwara z językiem komunikacji urzędowej, język poetycki sąsiaduje z językiem przejętym z sali sądowej. Čapek zaburza także hierarchię gatunków literackich pisząc opowiadania detektywistyczne, które w gruncie rzeczy można uznać za noetyczne opowiadania filozoficzne (Povídky z jedne kapsy, Povidky z druhé kapsy).

$\mathrm{Z}$ kolei w twórczości Milana Kundery różnorodność gatunkowa, wzajemne przenikanie się gatunków chyba najlepiej uwidacznia się w trzeciej powieści pisarza Valč́k na rozloučenou (1979). Powieść ta nosi cechy fraszki, ale jest jednocześnie komedią, tragedią i tekstem opartym na anegdocie. Utwór ten może być odczytany jako powieść polityczna, ale jednocześnie jako romans o banalnej tematyce. Nawet prozatorski debiut Kundery, zbiór opowiadań Směšné lásky, cechuje synkretyzm gatunkowy, pod pewnym względem można go nawet uznać za cykl opowiadań o cechach powieści z jednym centralnym tematem tworzącym główną oś utworu, jak sugeruje Reinhard Ibler (IBLER 2001: 598). Z kolei Kniha smíchu a zapomnění oceniana jako swego rodzaju polemika z teorią powieści, jest próbą rozszerzania marginesów i granic powieści jako gatunku (LE GRAND 1998: 
126) - poszczególne rozdziały łączy jedynie jedność tematów, motywów wariacji, kluczowych problemów. Podobnie jak w trylogii noetycznej Čapka - poszczególnych części trylogii nie łączy ani bohater, ani miejsce akcji, ale filozoficzna, noetyczna problematyka.

\section{Wieloznaczność prawdy i konieczność ciągłego poznawania}

Kundera, podobnie jak Čapek, w całej swojej twórczości skupia się na niejednoznaczności prawdy, świata, idei, polityki, kultury. Podkreśla i uświadamia, że mądrość polega właśnie na niepewności, na ciągłym stawianiu pytań, na poszukiwaniu odpowiedzi, na weryfikacji tego, co wydawać się może oczywiste. „Co je bez chvění, není pevné" - zdają się mówić i Kundera i Čapek, że posłużę się tytułem książki czeskiego teologa Tomáša Halíka, nota bene syna niestrudzonego edytora literackiej spuścizny Karla Čapka, Miroslava Halíka. Rozmywanie się znaczeń, przenikanie się granic jest widoczne chociażby w semantycznie „niepewnym" tytule ostatniej powieści Milana Kundery La Fête de l'insignifiance, co wnikliwie analizuje Svatava Urbanová: „Nakonec dospíváme k zjištění, že celý název není jednoznačný, jeho pochopení se liší vědomím souvislostí, orientací čtenáře a úrovní jeho vědomostního horizontu..." (UrBANOvá 2016: 4-5). Ową wieloznaczność i wieloznaczeniowość zawartą w tytule ostatniej powieści Kundery można uznać za kolejną odsłonę polifoniczności.

Według Silvii Richterowej powieści Kundery cechuje właśnie „mądra niepewność", mająca według badaczki swoje korzenie w silnym osobistym doświadczeniu totalitarnego systemu komunistycznego (Richterová 2004: 185). Kundera, podobnie jak Čapek, jest nieufny w stosunku do wszystkich wielkich prawd, wielkich idei, chce pozostać odporny na ułudę wielkich ideologii, odkrywa ich miałkość, pustkę. Obu autorów cechuje głęboka podejrzliwość w stosunku do wszystkiego, co monolityczne, jednoznaczne, zakładane a priori, przy jednoczesnym afirmatywnym stosunku obu autorów do wielości prawd. Wszystko, co człowieka otacza, nigdy nie jest gotowe, ukończone - prawda, tożsamość, wartości zawsze są in statu nascendi.

Właśnie przeciwko totalitaryzmowi prawdy w swoich utworach protestował Čapek, podkreślając niejednoznaczność wszystkiego, co człowieka otacza, podkreślając, że obowiązkiem człowieka jest nieustanna weryfikacja: weryfikacja własnej tożsamości, własnych uczuć, wersyfikacja swojej wiedzy o świecie, weryfikacja prawd, idei. Pozbawione refleksji wydawanie sądu, niepoprzedzone głębszym poznaniem, zastanowieniem się, prowadzi donikąd (JANIEC-NYITRAI 2016a). Właśnie głęboką niechęć międzywojennego pisarza do każdej absolutyzacji oznaczył Aleš Haman za jedną z kluczowych cech intelektualnego dziedzictwa Čapka: „byl to relativistický odpor k zjednodušujícímu a ideologizujícímu přístupu k člověku a jeho světu, v němž se jako nebezpečný ukazoval vznik metafyzicky nebo ideologicky absolutizovaných principů a idejí, které zbavovaly život jeho dramatického napětí, jeho dialektiky - zdroje tvůrčí povahy života" (HAMAN 2014: 12). 
Podobną właściwość możemy zaobserwować w przypadku Kundery, którego Eva Le Grand nazywa demaskatorem wszystkiego, co absolutne: „Kunderovo dílo - dílo jednoho z největších ironiků konce dvacátého století a nejnemilosrdnějšího demystifikátora všech Absoluten - nás totiž především poučuje o jedné základní 'pravdě': o absolutní relativitě každého lidského poznání, poznání druhých, sebe sama a stejně tak poznání každého autentického uměleckého díla" (LE GRAND 1998: 21).

Głęboka potrzeba nieustannego poznawania świata i siebie samego jest charakterystyczna dla całej twórczości Karla Čapka, co omawiałam już w artykule pt. Wydeptane gościńce, waskie ścieżki i manowce poznania. Noetyczna problematyka w twórczości Karla Čapka (JANIEC-NYITRAI 2015). Pojawia się ona jednak często także w utworach Kundery, począwszy od zbioru opowiadań Směšné lásky, w którym autor stawia pytania o granicę poznania własnej tożsamości (np. Falešný autostop). Jest to jeden z kluczowych tematów powracających w twórczości pisarza, na przykład w znanej scenie, kiedy Teresa, bohaterka powieści Nesnesitelná lehkost bytí, obserwuje swój nos: „Dívala se na sebe a představovala si, že by se její nos zvětšil každý den o milimetr. Za kolik dnů by se její tvář stala sobě nepodobná? A kdyby se různé části jejího těla začaly zvětšovat a zmenšovat, takže by se Tereza stala naprosto nepodobná sama sobě, byla by to ještě ona, byla by to ještě Tereza?" (KunDERA 2006: 149). Według Kundery scena ta nie odnosi się do problematyki ludzkiej cielesności, jak była często interpretowana, ale dotyka najbardziej podstawowych kwestii związanych z tożsamością i zaskoczeniem bohaterki niepewnością własnego ,ja” (KunDERA 1998: 33). Właśnie owa niepewna tożsamość, tożsamość chybotliwa, podlegająca ciągłej fluktuacji, pojawia się w powieści Čapka Obyčejný život. Kubiček, pisząc o ostatnich powieściach międzywojennego pisarza, stawia podstawowe pytania, jakie nasuwają się po lekturze trylogii noetycznej: „Do jaké míry je obraz člověka totožný s jeho skutečným vnímáním sebe sama? Co je 'pravda' ve světě rozděleném na individuální perspektivy, a tedy individuální 'spolehlivosti', když navíc toto rozdělení perspektiv (možností) je inkoherentní už vnitřnímu ustrojení člověka?” (KUBíčEK 2007: 139).

Podobne pytania jak Čapek stawia również Kundera w powieściach Žert, Kniha smichu a zapomněni albo Nesnesitelná lehkost bytí. Pozostaje to w zgodzie $\mathrm{z}$ koncepcją powieści jako pytania i powieściopisarstwa jako stawiania pytań, definiowania problemów, o której wnikliwie, właśnie w kontekście twórczości (WEBB 1990: 361). Powieść taka stoi według amerykańskiego badacza w całkowitej opozycji do powieści socrealistycznych, w których każde, najbardziej nawet niewinne pytanie, każda niejednoznaczność, mogła być odbierana jako zagrożenie (WeBB 1990: 361-362). Właśnie pytanie stoi w miejscu centralnym Kunderowskiej filozofii i poetyki powieści: „Být romanopiscem Kunderovi implikuje existenciální postoj založený na neustálém tázání po identitě a svobodě individua, na postoji, jenž je s to 'suspendovat každý morální soud' ve prospěch pochybovačství a relativnosti, které jsou prostorem par excellence pro ještě možné poznání, a tím i pro poznání vzdorující každému kategorickému souhlasu s politikou, náboženstvím, ideologii či morálkou, at’ už jsou jakékoli” (LE GRAND 1998: 77-78). 
To przecież w nieustannym stawianiu pytań, często bolesnych, niewygodnych, odkrywających tragiczną stronę ludzkiego losu realizuje się ów cień egzystencjalizmu, o którym pisała węgierska badaczka Ludmila Hankó (Hankó 2009: 66). Utwory Kundery nie są powieściami psychologicznymi, filozoficznymi, realistycznymi, jak wielokrotnie podkreśla sam autor, niemniej jednak odbijają się w nich właśnie sytuacje graniczne, wymuszające niejako formułowanie trudnych pytań.

\section{Różnica jako wartość}

W twórczości Karla Čapka często powraca motyw fascynacji różnorodnością, różnica, które czynią świat ciekawym i wartym poznawania. Odwrotną stroną fascynacji jest jednak strach przed uniformizacją przed zacieraniem się różnic, przed utratą własnej niepowtarzalności. Konkretne przykłady literackiej realizacji tej fascynacji przytoczyłam w artykule Každý rozdíl rozmnožuje život. Různé strategie uchopení odlišnosti v tvorbě Karla Čapka (JANIEC-NYITRAI 2010). U Kundery również pojawiają się podobne motywy: powodem niezliczonych podbojów miłosnych głównego bohatera powieści Nesnesitelná lehkost bytí Tomaša jest chęć poznania świata poprzez badanie różnic między kobietami, między ich ciałami, poprzez akt miłosny. „Odcházel od ní ve vynikající náladě. Snažil se upamatovat se na to podstatné, abstrahovat vzpomínku do jakéhosi chemického vzorce, jímž by bylo možno definovat její jedinečnost (milióntinu nepodobného). Došel nakonec k vzorci který se skládal ze tř́i údajů: 1) neobratnost spojená s horlivosti; 2) polekaná tvářně koho, kdo ztratil rovnováhu a padá; 3) nohy zvednuté do výše jako ruce vojáka, který se vzdává před napřaženou zbraní. Když si to opakoval, měl v soběštastný pocit, že se zase zmocnil kusu světa; že vyř́́zl svým imaginárním skalpelem proužek látky z nekonečného plátna vesmíru" (KUNDERA 2006: 222).

Jednym $z$ podstawowych motorów działania Tomaša jest właśnie poszukiwanie różnic, owej jednej milionowej części tego, co ludzi między sobą różni czyniąc ich wyjątkowymi, niepowtarzalnymi. Bohater pragnie określić dokładnie różnicę, zdefiniować ją, bo dopiero wtedy - poznając - ma wrażenie, że zdobywa świat, że czyni go swoim.

Unifikacja, zacieranie się różnic stanowi według Kundery jedno z największych zagrożeń współczesności. Wizja świata zamieszkałego przez braci i siostry „stworzonych" w dziwacznym eugenicznym eksperymencie przez jednego ojca doktora Škretę z Valčika na rozloučenou jest zapewne aluzją do unifikującego, znoszącego wszelkie różnice komunistycznego systemu totalitarnego. Strach przed unifikacją, przed postrzeganiem poprzez pryzmat gromady identycznych ciał towarzyszy Teresie z Nesnesitelné lehkosti bytí. Poeta Jaromil z powieści Život je jinde niestrudzenie stara się swoimi czynami potwierdzać własną wyjątkowość, utwierdzany w niej przez zaborczą matkę.

Swoją fascynację różnorodnością i protest przeciwko unifikacji świata manifestuje Kundera także w pracach eseistycznych. I tak na przykład w bodaj najbardziej znanym eseju Kundery Únos Západu aneb tragedie středni Evropy pojawia 
się myśl o sile i wartości Europy Środkowej, które od zawsze tkwiły właśnie w jej różnorodności. Europa Środkowa według Kundery zbudowana była zawsze na zasadzie zgromadzenia jak największej różnorodności na jak najmniejszej przestrzeni, odwrotnie niż Rosja (KUNDERA 2015: 155-156), co obrazowo uchwycił Vladimír Macura: „Rozmanitost Střední Evropy, vnímaná téměř jako její genetická vlastnost, je nabízena jako záchrana proti unifikaci, již podléhá Západní Evropa, i proti monolitnímu, zglajchšaltovanému Rusku jako cosi, co potenciálně je (či spíše bylo) nekonečně mnohotvárné a živoucí" (MACURA 1997: 17).

Kunderze i Čapkowi bliski jest zatem świat oparty na różnicy, a nie świat monolityczny, zhomogenizowany. Jedną z ważnych myśli przewodnich ich twórczości jest wiara w ludzką wyjątkowość, w siłę indywidualności, w niezniszczalność niepowtarzalności. Łączy ich także silna obawa przed wchłonięciem przez większość - masę, partię, ideologie, thum.

\section{„Ja” w oczach innych a rozpad tożsamości}

Tożsamość, zbudowana właśnie na różnicy w stosunku do innych ludzi, jest czymś niezwykle delikatnym, czymś, co podlega nieustannym zmianom, ale także pewnego rodzaju wykrzywieniom, zniekształceniom, wypaczeniom pod wpływem innych ludzi. Wspominany przeze mnie już kilkukrotnie Kubíček w sposób przenikliwy definiuje to zjawisko: „Mezi člověka a ty druhé je položen obraz, zrcadlo sebeprojekce. Jedinečnost člověka se ztrácí v předjednaných rámcích" (KuBíČEK 2012: 80). Problem ten pojawia się wyraźnie w twórczości Čapka. Hordubal w oczach innych bohaterów powieści jest zwykłym, prymitywnym wieśniakiem, wszyscy oceniają go według własnych kryteriów. Tytułowy bohater istnieje właściwie jedynie jako wypadkowa opinii, które wystawiają o nim inne postaci, obraz ten jest nieuchronnie zdeformowany, co czytelnik ma możliwość zweryfikowania na podstawie monologów wewnętrznych bohatera. Wielowymiarowość człowieka zostaje $\mathrm{w}$ taki sposób zniszczona, zostaje mu nasadzona gombrowiczowska „gęba”. Ten sam los przypada w udziale Taminie z Knihy smichu a zapomnění: „Tamina $\mathrm{v}$ rozhovorech mlčí, protože není tázána, poslouchá ty ostatní a jen pozoruje, jak se její prátelé zmocňují jejího obrazu, který se pro ně stává důležitější než sama Tamina. Jeho autory jsou však ve skutečnosti oni sami. Tamina se za ním ztrácí, zaniká" (KuBíčEK 2012: 81), czy Sabinie z Nesnesitelné lehkosti bytí, która przez ludzi z Europy Zachodniej postrzegana jest wyłącznie poprzez pryzmat swojej emigracji i sytuacji politycznej w Czechosłowacji. Nie istnieje jako osobny, niezależny byt, dla wszystkich jest jedynie emigrantką. Jej obrazy są interpretowane jedynie przy pomocy klucza politycznych doświadczeń, tym samym podlegają okrutnej redukcji i kastracji znaczeń.

Według Kundery powieść ma być właśnie swego rodzaju protestem przeciwko redukcji, ma za zadanie podać jak najszerszy, możliwie najbardziej złożony obraz rzeczywistości, choć jednocześnie Kundera zdaje sobie sprawę z niemożności oddania złożoności świata (KUNDERA 1998: 24-25). Podobnie Čapek stawiał sobie za cel pokazanie jak najszerszego spektrum ludzkiego doświadczenia, oddanie 
chropowatości struktury rzeczywistości, ludzkiego charakteru, chropowatości prawdy i cienkiej granicy dzielącej poszczególne uczucia, idee czy wartości.

Tożsamość bohaterów powieści Kundery podlega nieustannym deformacjom, okrutnym eksperymentom. Zaobserwować to możemy na przykładzie ,autostopowiczki" z opowiadania Falešný autostop, która przystępuje do gry, kończącej się tragicznym rozchwianiem tożsamości: powtarza mechanicznie ,ja, to ja”, ale zaczyna zdawać sobie sprawę z tego, że tożsamość nie jest dana raz na zawsze, lecz trzeba ją nieustannie definiować i sprawdzać jej zarysy, ponieważ pod wpływem okoliczności może ulegać rozmaitym aberracjom. Pełny rozpad tożsamości opisał Čapek w powieści Obyčejný život, w której tytułowy „zwyczajny człowiek” dokonuje w obliczu śmierci wiwisekcji własnego ,ja”. Zauważa, że sam sobie nakładał gombrowiczowską , gębę”, że sam retuszował własne czyny, że sam żył w fałszu. Nagle zauważa, jak wiele osobowości - „niezrealizowanych żywotów” w nim drzemało, jak niejednoznaczna była jego droga życiowa. Tym samym u Čapka i Kundery problematyka granic własnej tożsamości i ograniczeń wynikających z wyborów, które zostały podjęte, staje się jednym z tematów przewodnich ich twórczości.

\section{Nierealizowane możliwości}

„Ale každému člověku se stýská, že nemohl žít jiné životy než ten jeden jediný, i vy byste rádi prožili všechny své neuskutečněné možností, všechny své možné životy" (KundERA 1979: 307). To zdanie, pochodzące z początku szóstego rozdziału powieści Život je jinde wydaje się być jakby słowo w słowo wyjęte z utworów Karla Čapka. W opowiadaniu Sbirka známek jeden z bohaterów międzywojennych opowiadań czeskiego pisarza rozważa w podobny sposób kwestię niezrealizowanych możliwości: „Kdyby se člověk hrabal ve své minulosti, našel by, že v ní je dost látky na docela jiné životy. Jednou... bud' omylem, nebo z náklonnosti... si vybral jenom jeden z nich a dožívá jej až do konce; ale nejhorší je, že ty druhé, ty možné životy nejsou tak docela mrtvé. A někdy se stane, že v nich pocítíš bolest jako v uříznuté noze" (ČAPEK 1961: 280).

Refleksje dotyczące niezrealizowanych, lecz możliwych wariantów życia każdego człowieka Čapek pogłębia w ostatniej części trylogii noetycznej, gdzie pokazuje, że właśnie te niezrealizowane możliwości, niewybrane drogi, zmarnowane szanse pozwalają nawiązać porozumienie między ludźmi, są punktem styczności. Całe ludzkie życie jawi się jako niezrealizowana możliwość (JANIEC-NYITRAI 2016b: 53).

Temat ten jest atrakcyjny także dla Kundery, który w swojej Sztuce powieści podkreśla, iż pisarz odkrywa możliwości, a nie rzeczywistość: „Powieściopisarze kreślą mapę egzystencji odkrywając tę czy inną ludzką możliwość. Ale powtórzmy raz jeszcze: istnieć oznacza 'być-w-świecie'. Należy zatem rozumieć i bohatera, i jego świat jako możliwość" (KunDERA 1998: 44). W ten sposób właśnie pisarz żyje w konkretnych losach poszczególnych stworzonych przez siebie postaci, może dzięki temu więcej przeżyć, głębiej badać splątane labirynty rzeczywistości, 
staje się w ten sposób, podobnie jak bohaterowie Čapka, wyczulony na problemy innych, bardziej empatyczny. W utworach Kundery wyraźniej widoczny jest żal za utraconymi i niezrealizowanymi możliwościami, choć podobne smutne tony da się także zaobserwować u Čapka, szczególnie w kontekście poznawczym. Čapek tęskni za poznaniem kompletnym, za widzeniem z różnych perspektyw. Olga Scheinpflugová, małżonka czeskiego pisarza, przytacza niezachowany list od niego: „Můj bože, moci vidět všemi zraky najednou, jaky by to byl slavny a požehnany život! Vidět očima maliře, zrakem sochaře, basnika, zahradnika, stavitele, tesaře, očima hornika, ženy a ditěte" (ScheinPflugová 1947: 213-214). Widzieć w tym można przejmujące świadectwo marzenia o pełnym widzeniu, o pełnym poznaniu, o całkowitym wyzbyciu sie okularów iluzji (vide Komeński), co siłą rzeczy jest niemożliwe.

\section{Wnioski końcowe}

Z zarysowanych przeze mnie analogii w pisarstwie Kundery i Čapka wyraźnie wyłania się wniosek o istniejącym między obu pisarzami twórczym pokrewieństwie, przy czym podobieństwa między ich sposobem widzenia świata i artystyczną sublimacją tegoż widzenia wydają się głębsze, niż się na pierwszy rzut oka wydaje. Możliwe jednak, że Kundera wielokrotnie powraca do motywów pojawiających się w twórczości międzywojennego pisarza w sposób bezwiedny. Możliwe też, że obaj pisarze zostali obdarzeni podobną wrażliwością, wyczuleniem na podobne problemy, a tym samym rozpoznają uniwersalne prawa, którymi rządzi się świat.

Niektóre analogie w twórczości Čapka i Kundery pojawiają się jakby przy okazji i są związane z trudnym do uchwycenia pokrewieństwem umysłowym i filozoficznym obu pisarzy. I Ćapek, i Kundera czerpią z tej samej racjonalistycznej wizji świata, opartej na rozumowym, analitycznym podejściu, które jednakże jest wciąż podważane, naruszane poprzez opatrzenie go znakiem zapytania. Wielokrotnie przeze mnie tu przywoływany Kubíček we wstępie do swojej książki Středoevropan Milan Kundera wspomina właśnie, jak się okazuje nie bez przyczyny, Karla Čapka i jego filozofię zawartą w zbiorze opowiadań Boži muka: „Bezradnost člověka ve vztahu ke světu, který se vzpírá rozumové analýze a pojmenování a zpupně si uchovává své tajemství, je i součástí neřešitelného problému, který zakouší v Božích mukách Čapkův Boura (citující Davida Huma), když stojí nad osamělou šlépějí ve sněhu. Tento odpor, který moderní svět a člověk klade racionální analýze, je i základním klíčem k Capkově noetické trilogií. Zneklidňující nepoznatelnost podvrací pýchu rozumu" (KUBíčEK 2012: 20).

W twórczości Milana Kundery owa niepoznawalność świata, z którą tak trudno się pogodzić, jest stale obecna. Podobnie jak frustracja płynąca z niemożności odsłonięcia kurtyny zasłaniającej świat, którą Kundera stara się zerwać właśnie za pomocą rozumu.

W artykule zasygnalizowałam wyraźnie widoczne paralele w twórczości Kundery i Čapka, ale pojawiają się także dalsze tropy, którymi można by podążać, 
np. porównanie niedokończonej powieści Život a dílo skladatele Foltýna z powieścią Kundery Život je jinde (HAMAN 2014: 272). Wydaje się, iż wzajemne powiązania obu autorów są o wiele bliższe niż do tej pory sądzono i że istnieje między ich dziełami ważna zależność, zasługująca na dokładne przebadanie.

\section{Literatura}

ČAPEK 1961 = ČAPEK Karel: Povidky z jedné kapsy. Povídky z druhé kapsy. Praha: Československý spisovatel, 1961.

GRZENIA 1999 = GRZENIA Jan: Język poetycki jako struktura polifoniczna. Na materiale poezji polskiej XX wieku. Katowice: Wydawnictwo Uniwersytetu Śląskiego, 1999.

Haman 2014 = Haman Aleš: Tři stálice moderni české prózy: Neruda, Čapek, Kundera. Praha: Karolinum, 2014.

HANKÓ 2009 = HANKÓ B. Ludmila: Jegyzetek Milan Kundera nyolcvanadik születésnapjára. Bohemia 17 (2009): 65-67.

ChVATíK 1994 = CHVATík Květoslav: Svět románů Milana Kundery. Brno: Atlantis, 1994.

IBLER 2001 = IBLER Reinhard: Na hranicích románu: Kunderovy Směšné lásky. In: Česká literatura na konci tisícileti 2. Praha: Ústav pro českou literaturu AV, 2001. 595-600.

JANIEC-NyitRAi 2010 = JANIEC-NYITRAi Agnieszka: „Každý rozdíl rozmnožuje život”. Různé strategie uchopení odlišnosti v tvorbě Karla Čapka. In: JunGMANNOVÁ Lenka (red.): Česká literatura rozhraní a okraje. IV. kongres světové literárnovědné bohemistiky. Praha: Ústav pro českou literaturu AV ČR, 2010. 205-213.

JANIEC-NYITRAI 2015 = JANIEC-NYITRAI Agnieszka: Wydeptane gościńce, wąskie ścieżki i manowce poznania. Noetyczna problematyka w twórczości Karla Čapka. In: GoŁACHOwska Ewa, PAZIO-WlazŁowsKa Dorota (red.): Konstrukcje i destrukcje tożsamości. T. 4. Wartości w świecie słowiańskim. Warszawa: Instytut Slawistyki Polskiej Akademii Nauk, 2015. 127-140.

JANIEC-NyITRAi 2016a = JANIEC-NyITRAi Agnieszka: Potřeba nekonečné verifikace. Hrdinové próz Karla Čapka na klikatých cestách poznání. In: RusınOvÁ Eva (red.): Přednášky a besedy ze XLIX. ročníku Letni školy slovanských studii. Brno: Masarykova univerzita, 2016. 60-72.

JANIEC-NyITRAi 2016b = JANIEC-NyITRAI Agnieszka: V labyrintu možností. Dvanáct literárněvědných studii o próze Karla Čapka. Budapest: ELTE, 2016.

KLIŚ 2011 = KLIŚ Beata: Polifonia czyli wielogłosowość tekstu literackiego w wybranych tekstach prozatorskich Olgi Tokarczuk i Andrzeja Stasiuka. LingVaria 2001/2: 25-34.

Kosková 1996 = KoskovÁ Helena: Hledání ztracené generace. Praha: H\&H, 1996.

KuBíČEK 2007 = KuBÍČEK Tomáš: Vypravěč. Kategorie narativní analýzy. Brno: Host, 2007.

KuBíČEK 2012 = KuBíčEK Tomáš: Středoevropan Milan Kundera. Olomouc: Periplum, 2012.

KunderA 1979 = KunderA Milan: Život je jinde. Toronto: Sixty Eight Publishers, 1979.

KunderA 1998 = KunderA Milan: Sztuka powieści. Warszawa: PIW, 1998.

Kundera 2006 = Kundera Milan: Nesnesitelná lehkost bytí. Brno: Atlantis, 2006.

KunderA 2014 = KunderA Milan: Slova, pojmy, situace. Brno: Atlantis, 2014.

Kundera 2015 = Kundera Milan: Únos Západu. In: VArgová Zuzana (red.): Koncepcie strednej Európy. Antológia textov. Nitra: UKF, 2015. 153-162.

Le Grand 1998 = Le Grand Eva: Kundera aneb Pamět touhy. Olomouc: Votobia, 1998. 
MACURA 1997 = MACURA Vladimír: Sémiotika Evropy. In: HAHNOvÁ Eva (red.): Evropa očima Čechů. Praha: Nakladatelství Franze Kafky, 1997. 9-24.

PoHORSKÝ 1990 = PoHORSKÝ Miloš: Zlomky analýzy. Praha: Československý spisovatel, 1990.

Richterová 2004 = Richterová Silvie: Místo domova. Brno: Host, 2004.

ScheinPflugová 1947 = ScheinPflugová Olga: Český román. Praha: Fr. Borový, 1947.

URBANOVÁ 2016 = URBANOVÁ Svatava: Reflexe bezvýznamnosti a její možností zření.

Milan Kundera: Oslava bezvýznamnosti - La fiesta de la insignificancia. Bohemistyka 16: $3-18$.

WeBb 1990 = WeBB Igor: Milan Kundera and the Limits of Scepticism. The Massachusetts Review 31 (1990): 357-368. 